\title{
Survei Entomologi, Maya Indeks, dan Status Kerentanan Larva Nyamuk Aedes aegypti terhadap Temephos
}

\author{
Tiya Taslisia ${ }^{1}$, Selfi Renita Rusjdi ${ }^{2}$, Hasmiwati $^{3}$
}

\begin{abstract}
Abstrak
Demam berdarah dengue (DBD) adalah salah satu penyakit menular yang merupakan masalah kesehatan dan sudah menjadi perhatian di dunia. Data selama 50 tahun terakhir, kasus DBD meningkat hingga 30 kali lipat. Peningkatan kasus DBD berhubungan dengan kepadatan nyamuk, maya indeks, dan status kerentanan disuatu daerah. Tujuan penelitian ini adalah menentukan kepadatan nyamuk $(\mathrm{HI}, \mathrm{Cl}, \mathrm{BI})$, maya indeks dan status kerentanan larva Aedes aegypti terhadap Temephos $0.012 \mathrm{mg} / \mathrm{L}$. Penelitian telah dilakukan di Desa Salido Kecamatan IV Jurai Kabupaten Pesisir Selatan pada bulan Desember 2017- Februari 2018 dengan 100 rumah menjadi sampel yang dibagi secara proporsional berdasarkan banyak rumah di kelompok tertentu. Pengamatan dan pencatatan dilakukan pada tempat penampungan air yang berada di dalam dan di luar rumah dan mengambil semua larva yang ditemukan. Larva yang didapatkan diuji di Laboratorium Parasitologi Fakultas Kedokteran Universitas Andalas. Hasil penelitian di dapatkan nilai $\mathrm{HI} 57 \%$, Cl 22.04\%, BI 123\% dengan nilai rerata DF 7 artinya kepadatan tinggi. Nilai CS $77.42 \%$ didapatkan lebih tinggi dari DS 22.58\% dengan total kontainer berjumlah 558 buah. Maya indeks didapatkan 93 rumah dengan risiko rendah dan 7 dengan risiko sedang. Uji kerentanan dengan Temephos 0.012 didapatkan sudah terjadi resistensi.
\end{abstract}

Kata kunci: Aedes aegypti, kepadatan nyamuk, maya indeks, uji kerentanan

\section{Abstract}

Dengue hemorrhagic fever is one of the infectious diseases which has become a health problem and is an attention to the world. According to the data in the last 50 years, the case has increased by 30 times. It may be related to the density $(\mathrm{HI}, \mathrm{Cl}, \mathrm{BI})$, Maya Index, and the resistance of Ae. aegypti within the area. The objective of this study was to determine the density, maya index, and resistance status of Ae. aegypti agains Temephos $0.012 \mathrm{mg} / \mathrm{L}$. This study was done in Salido Vilage Subdistric IV Jurai Pesisir Selatan from December 2017 - February 2018 at 100 houses by using proportional stratified random sampling. The data was collected by observing the water reservoir outside and inside the house and collected the larvae. Larva was then tested at Parasitology Laboratory of Andalas University. The study showed that Density Figure is at High level, which was $57 \% \mathrm{HI}, 22.58 \% \mathrm{Cl}, 123 \% \mathrm{BI}$. The value of CS $(77.42 \%)$ was higher than DS $(22.58 \%)$ and there was a total of 558 containers. The Maya index count showed that low potential home was $93 \%$, and moderate potential was $7 \%$. The resistance was tested by using $0,012 \mathrm{mg} / \mathrm{L}$ Temephos larvae of Ae. aegypti and was confirmed to be resistant.

Keywords: Aedes aegypti, density figure, maya index, test susceptibility

Affiliasi penulis: 1. Prodi Pendidikan Dokter Fakultas Kedokteran Universitas Andalas Padang (FK Unand); 2. Bagian Parasitologi FK Unand 3. Bagian Parasitologi FK Unand
Korespondensi: Tiya Taslisia , Email:

Taslisiatiya@yahoo.co.id Telp: 082174127528 


\section{PENDAHULUAN}

Demam berdarah dengue (DBD) merupakan penyakit akibat virus dengue yang ditularkan oleh vektor nyamuk Aedes aegypti yang menyebar cepat. Berdasarkan data selama 50 tahun terakhir, kasus DBD meningkat hingga 30 kali lipat dengan peningkatan ekspansi geografis ke negara baru, terutama dari kota ke lokasi pedesaan. ${ }^{1}$

Penderita DBD dilaporkan sebanyak 129.650 di 34 provinsi di Indonesia, dan 1.071 orang di antaranya meninggal dunia (Incidence Rate (IR) yaitu 50,75 per 100.000 penduduk dan Case Fatality Rate (CFR) yaitu 0,83\%) pada tahun 2015. Jumlah tersebut lebih tinggi dibandingkan tahun sebelumnya, yakni 100.347 kasus dengan jumlah kematian sebanyak 907 orang (IR yaitu 39,8 per 100.000 penduduk dan CFR yaitu $0,90 \%{ }^{2,3}$

Usaha pemerintah dalam aspek kuratif telah berhasil menurunkan CFR bagi penderita DBD, namun IR cenderung mengalami kenaikan dan penyebaran kasus yang meluas ke pelosok daerah. Hal ini terjadi karena belum ditemukan vaksin spesifik antigen dengue untuk mencegah penularan DBD. WHO telah menetapkan bahwa penanganan DBD yang efektif adalah dengan melakukan pengendalian vektor baik pada stadium larva maupun stadium dewasa. ${ }^{4}$

Penanggulangan DBD diperlukan data lingkungan berupa tempat perkembangbiakan nyamuk, yaitu Maya Indeks (MI). Analisis MI digunakan untuk mengidentifikasi suatu area berisiko tinggi sebagai tempat perkembangbiakan (breeding site) larva. Ml menggunakan indikator Hygiene Risk Index (HRI) yaitu keadaan kebersihan lingkungan rumah dan Breeding Risk Index (BRI) yaitu ketersediaan tempat-tempat yang mungkin berpotensi sebagai tempat perkembangbiakan nyamuk di dalam rumah. Kedua indikator tersebut dikategorikan menjadi tiga, yakni tinggi, sedang, dan rendah yang membentuk Tabel $3 \times 3 .{ }^{5}$

Penyebaran penyakit DBD didukung oleh tiga faktor yaitu manusia, virus, lingkungan dan vektor penular. Penanggulangan DBD yang dapat dilaksanakan saat ini adalah dengan mengendalikan vektornya, dengan menekan populasi nyamuk Aedes spp. ${ }^{6}$ Indonesia menetapkan pengendalian vektor yang utama adalah pemberantasan sarang nyamuk (PSN) yaitu menguras, menutup dan mengubur tempat penampungan air yang memiliki potensi menjadi tempat hidup bagi Ae. aegypti plus penggunaan insektisida. Gerakan PSN ini masih banyak mengalami kendala operasional dalam masyarakat, sehingga kasus DBD terus mengalami peningkatan. ${ }^{7}$ Pemerintah melalui komisi pestisida menetapkan bahwa pengendalian vektor dapat dilakukan dengan penggunaan insektisida kimia dengan ketentuan tertentu, satu diantaranya adalah larvasida Temephos. ${ }^{8}$

Temephos merupakan larvasida sintetik golongan organofosfat yang digunakan untuk membunuh larva Ae. aegypti di tempat persediaan air bersih penduduk dengan cara menghambat hantaran impuls saraf. ${ }^{9}$ Formulasi Temephos yang dibagikan kemasyarakat adalah granul (sand granul) dosis yang digunakan 1 ppm untuk setiap 100 liter air. Abatisasi ini mempunyai efek residu 12 minggu. Formulasi lainnya adalah dalam bentuk liquid yang efeknya cepat. ${ }^{10}$ Penelitian Sungkar mengungkapkan bahwa pemakaian insektisida sintetik secara terus menerus dan berulang sebagai upaya pengendalian Ae. aegypti dapat menimbulkan pencemaran lingkungan, membunuh fauna lain, hingga terjadinya resistensi vektor. $^{11}$

Data surveilans kepadatan nyamuk Ae. aegypti dan Ae. albopictus dapat diukur menggunakan indikator entomologi yaitu Container Index $(\mathrm{Cl})$, House Index (HI), dan Breteau Index (BI). Hasil perhitungan tersebut kemudian dibandingkan dengan angka kepadatan vektor (density figure) dari WHO. Risiko penularan DBD nanti dikategorikan ringan, sedang, dan berat berdasarkan density figure. Indikator entomologi sangat efektif dipergunakan dalam pemantauan daerah rawan yang sering terjadi kasus DBD sehingga dapat mengantisipasi munculnya kasus baru. ${ }^{12,13}$

Tingginya kasus DBD ini dapat berhubungan dengan kepadatan dan resistensi yang telah terjadi pada nyamuk $A e$. aegypti, ditambahkan dengan belum terlaksananya program jumantik di Desa Salido yang didapatkan dari hasil wawancara dengan staf surveilens dan penanggung jawab DBD Puskesmas 
Salido, sehingga perlu diteliti indikator kepadatan nyamuk dan status kerentanan larva nyamuk $A e$. aegypti terhadap Temephos 0,012 mg/L yang berada di Kecamatan IV Jurai Desa Salido Kabupaten Pesisir Selatan.

\section{METODE}

Jenis penelitian ini adalah deskriptif dengan metode crossectional dimana pada semua variabe dilakukan pengamatan secara bersama dalam satu waktu, untuk menggambarkan indikator entomologi, maya indeks dan status kerentanan larva nyamuk $A e$. aegypti di Desa Salido Kecamatan IV Jurai Kabupaten Pesisir Selatan.

Populasi penelitian adalah rumah warga di Desa Salido Kecamatan IV Jurai Kabupaten Pesisir Selatan untuk dilakukan survei jentik serta pengambilan jentik nyamuk, dan untuk selanjutnya dilakukan uji resisten di Laboratorium Parasitologi FK Unand.

Sampel penelitian adalah 100 rumah di wilayah desa. Jumlah ini sesuai dengan standar minimal yang ditetapkan oleh WHO. ${ }^{14}$ Menguji status kerentanan larva besar sampel yang diperlukan adalah 20 ekor larva instar 3 pada satu perlakuan. Perlakuan ini dilakukan $3 x$ pengulangan sesuai dengan $\mathrm{WHO}{ }^{15}$
Teknik pengambilan sampel yang dipilih adalah proportionate stratified random sampling yaitu teknik pengambilan sampel yang memberikan peluang yang sama bagi setiap kelompok populasi untuk dipilih menjadi anggota, setelah ditentukan jumlah anggota yang dijadikan sampel maka dilakukan pengacakan dari total anggota yang ada di Desa Salido ini.

\section{HASIL}

Hasil penelitian pada 100 rumah di Desa Salido Kecamatan IV Jurai Kabupaten Pesisir Selatan yang terdapat pada Tabel 1 terdapat 57 rumah positif larva nyamuk yang berarti nilai House Index $(\mathrm{HI})$ adalah $57 \%$. Perhitungan kontainer terdapat 558 jumlah kontainer, 123 kontainer positif larva dan 432 tidak ditemukan larva nyamuk. Nilai Container Index $(\mathrm{Cl})$ didapatkan adalah 22.04\%. Nilai Breteau Index (BI) adalah $123 \%$. Penelitian yang dilakukan di Desa Salido Kacamatan IV Jurai Kabupaten Pesisir Selatan didapatkan $\mathrm{HI} 57 \%$ setara dengan DF 7, Cl 22.04\% setara dengan DF $6, \mathrm{BI} 123 \%$ setara dengan DF 8 . Total dari nilai DF yang didapatkan dari $\mathrm{HI}, \mathrm{Cl}, \mathrm{BI}$ dirata-ratakan dan didapatkan DF adalah 7 .

Tabel 2 terdapat angka yang tinggi pada Controllable Site (CS) yaitu $77.42 \%$ dan angka yang rendah pada Diposable Site (DS) yaitu $22.58 \%$.

Tabel 1. Distribusi larva di Desa Salido Kecamatan IV Jurai Kabupaten Pesisir Selatan

\begin{tabular}{clccccccc}
\hline \multirow{2}{*}{ No } & Diperiksa & Jumlah & \multicolumn{2}{c}{ Larva } & HI \% & CI \% & BI \% & DF \\
\cline { 3 - 6 } & & & Ada & Tidak & & & \\
\hline 1 & Rumah & 100 & 57 & 43 & $57 \%$ & $22.04 \%$ & $123 \%$ \\
2 & Kontainer & 558 & 123 & 435 & & & \\
\hline
\end{tabular}

Tabel 2. Distribusi kontainer berdasarkan kategori di Desa Salido Kecamatan IV Jurai Kabupaten Pesisir Selatan

\begin{tabular}{lll}
\hline \multicolumn{1}{c}{ Kategori } & \multicolumn{1}{c}{ Kontainer } \\
\cline { 2 - 3 } & Jumlah & $\%$ \\
\hline Controllable Site (CS) & 432 & $77.42 \%$ \\
Diposable Site (DS) & 126 & $22.58 \%$ \\
Uncontrollable Site (US) & 0 & 0 \\
Total & 558 & $100 \%$ \\
\hline
\end{tabular}


Tabel 3 memperlihatkan 100 rumah yang diperiksa terdapat 99 rumah dengan $\mathrm{HRI}$ rendah dan 1 rumah dengan $\mathrm{HRI}$ tinggi. Pada perhitungan BRI terdapat 92 rumah dengan BRI rendah, 2 rumah dengan BRI sedang dan 6 rumah dengan BRI tinggi. Nilai maya indeks berdasarkan perhitungan terdapat 93 rumah dengan maya indeks rendah dan 7 rumah dengan maya indeks sedang.

Hasil survei larva dapat dilihat pada Tabel 4 yang menunjukan bahwa tempat penampungan air yang diperiksa di Desa Salido Kecamatan IV Jurai Kabupaten Pesisir Selatan berjumlah 558 kontainer dengan 123 kontainer yang positif larva. Proporsi CS terdapat 432 kontainer dengan 81 kontainer yang positif. Jenis CS dengan jumlah terbanyak dan positif jentik terbanyak adalah ember dengan jumlah 266 dan positif 44. Jumlah terendah untuk CS adalah gentong, talang air dan tempat minum burung. Proporsi DS lebih rendah dari CS yaitu terdapat 126 kontainer dengan 42 kontainer yang positif larva. Jenis DS dengan jumlah terbanyak diember bekas dan jumlah positif terbanyak adalah di ban bekas. Jumlah terendah DS adalah toples bekas dan gelas bekas.

Tabel 5 didapatkan total kematian dalam tiga kali pengulangan adalah 5 larva dengan total persentase kematian sebesar $25 \%$ dan rata-rata persentase kematian larva pada uji dengan menggunakan Temephos $0.012 \mathrm{mg} / \mathrm{L}$ adalah $8.33 \%$. Larva di Desa Salido Kecamatan IV jurai Kabupaten Pesisir Selatan dikatakan sudah resisten terhadap Temephos $0.012 \mathrm{mg} / \mathrm{L}$.

Tabel 6 dilakukan uji statistik dengan analisis probit kepercayaan 95\%, maka di dapatkan waktu untuk membunuh 50\% larva Ae. aegypti dibutuhkan waktu 1826 menit. Membunuh 99\% larva Ae. aegypti dibutuhkan waktu 2475.42 menit.

Tabel 3. Distribusi frekuensi rumah berdasarkan HRI dan BRI di Desa Salido Salido

\begin{tabular}{cccc}
\hline Kategori & Hygine Risk index (HRI) & Breeding Risk Index (BRI) & \\
\hline Rendah & 99 & 92 & 93 \\
Sedang & 0 & 6 & 7 \\
Tinggi & 1 & 100 & 0 \\
Total & 100 & & 100 \\
\hline
\end{tabular}


Tabel 4. Distribusi kontainer yang positif larva berdasarkan jenis kontainer di Desa Salido Pesisir Selatan

\begin{tabular}{|c|c|c|}
\hline \multirow[t]{2}{*}{ Jenis TPA } & \multicolumn{2}{|c|}{ Kontainer } \\
\hline & Jumlah & Positif \\
\hline Controllable Site (CS) & 432 & 81 \\
\hline Bak Mandi & 100 & 27 \\
\hline Ember & 266 & 44 \\
\hline Pot Bunga & 2 & 0 \\
\hline Drum & 6 & 0 \\
\hline Sumur & 43 & 8 \\
\hline Dispenser & 9 & 1 \\
\hline Jerigen & 5 & 0 \\
\hline Tempat minum burung & 0 & 0 \\
\hline Talang air & 0 & 0 \\
\hline Gentong & 0 & 0 \\
\hline Tempat air minum & 1 & 1 \\
\hline Diposable Site (DS) & 126 & 42 \\
\hline Kaleng bekas & 21 & 6 \\
\hline Botol bekas & 11 & 0 \\
\hline Ban bekas & 28 & 21 \\
\hline Ember bekas & 43 & 12 \\
\hline Toples bekas & 0 & 0 \\
\hline Gelas bekas & 0 & 0 \\
\hline Drum bekas & 11 & 1 \\
\hline Tempurung dan tempat makan unggas bekas & 12 & 2 \\
\hline \multicolumn{3}{|l|}{ Under controllable site } \\
\hline Kolam ikan & 0 & 0 \\
\hline Akuarium & 0 & 0 \\
\hline Total & 558 & 123 \\
\hline
\end{tabular}

Tabel 5. Jumlah kematian larva Ae. aegypti dengan menggunakan Temephos $0.012 \mathrm{mg} / \mathrm{L}$ di Desa Salido

\begin{tabular}{|c|c|c|c|c|c|c|c|c|}
\hline \multirow[t]{2}{*}{ Ulangan } & \multirow{2}{*}{$\begin{array}{c}\text { Jumlah } \\
\text { Larva }\end{array}$} & \multicolumn{5}{|c|}{ Waktu } & \multirow[t]{2}{*}{ Total kematian } & \multirow[t]{2}{*}{$\%$ kematian } \\
\hline & & 15 menit & 30 menit & 45 menit & 60 menit & 24 jam & & \\
\hline U1 & 20 & 0 & 0 & 0 & 0 & 3 & 3 & 15 \\
\hline U2 & 20 & 0 & 0 & 0 & 0 & 1 & 1 & 5 \\
\hline U3 & 20 & 0 & 0 & 0 & 0 & 1 & 1 & 5 \\
\hline Kontrol & 20 & 0 & 0 & 0 & 0 & 0 & 0 & 0 \\
\hline Total & 80 & & & & & & & 25 \\
\hline Rerata & & & & & & & & $8.33 \%$ \\
\hline
\end{tabular}

Tabel 6. LT50 dan LT99 terhadap Temephos 0.012 di Desa Salido

\begin{tabular}{ccc}
\hline No & Kematian Larva Ae. aegypti & Estimate \\
\hline 1 & LT 50 & 1826.77 \\
2 & LT 99 & 2475.42 \\
\hline
\end{tabular}




\section{PEMBAHASAN}

\section{Survei Entomologi ( $\mathrm{HI}, \mathrm{BI}, \mathrm{Cl})$}

House Index (HI) merupakan indikator yang digunakan untuk memonitoring rumah yang positif larva dari jumlah rumah yang diperiksa. Menurut WHO, suatu wilayah dikatakan berisiko tinggi apabila suatu wilayah mempunyai nilai $\mathrm{HI}>5 \%$, sedangkan berisiko rendah bila nilai $\mathrm{HI}<1 \%$. Semakin tinggi nilai $\mathrm{HI}$ maka semakin tinggi pula kepadatan nyamuk dan semakin tinggi juga risiko penularan penyakit DBD. ${ }^{14}$

Hasil penelitian di Desa Salido Kecamatan IV Jurai Kabupaten Pesisir Selatan ditemukan rumah positif larva pada penampungan air sebesar 57 rumah $(57 \%)$. Penentuan risiko penularan berdasarkan nilai $\mathrm{HI}$ termasuk kriteria $\mathrm{HI}$ tinggi, artinya bahwa kepadatan larva di Desa Salido Kecamatan IV Jurai Kabupaten Pesisir Selatan memiliki risiko tinggi untuk terjadi penularan penyakit DBD. Faktor yang dapat mempengaruhi tingginya nilai $\mathrm{HI}$ adalah perilaku dan partisipasi masyarakat yang masih kurang dalam kegiatan Pemberantasan Sarang Nyamuk (PSN). ${ }^{3}$ Program PSN 3M plus berdasarkan kemenkes adalah menguras, menutup dan memanfaatkan barang bekas, melakukan larvasidasi, pengendalian biologis dengan memelihara ikan pemakan jentik dan menggunakan alat proteksi diri seperti kelambu, repellent. ${ }^{16}$ Data dari lapangan saat melakukan survei entomologi, beberapa masyarakat tidak melakukan program PSN 3M plus sesuai dengan aturan seperti tidak melakukan pengurasan bak mandi secara teratur yang akan mempengaruhi nilai $\mathrm{HI}$.

Hasil penelitian yang sesuai adalah penelitian Habibie et al (2017) didapatkan nilai $\mathrm{HI} 38 \%$ di Kelurahan Ibuh Payakumbuh yang memiliki kriteria HI tinggi artinya kepadatan di Kelurahan Ibuh cukup untuk mempermudah terjadinya perkembangan DBD. $^{17}$

$\mathrm{Cl}$ menggambarkan jumlah penampungan air yang positif larva dari jumlah penampungan air yang diperiksa. Nilai $\mathrm{Cl}$ yang didapatkan dari penelitian di Desa Salido Kecamatan IV Jurai Pesisir Selatan adalah $22.04 \%$ termasuk kategori memiliki risiko tinggi. Apabila suatu wilayah mempunyai $\mathrm{Cl}>5 \%$ berarti risiko tinggi, sedangkan apabila $\mathrm{Cl}$ kurang $<5 \%$, maka berarti risiko rendah penyakit DBD. ${ }^{14}$
Jenis kontainer yang paling banyak ditemukan positif larva di dalam rumah di Desa Salido adalah ember $61 \%$ diikuti oleh bak mandi $23 \%$. Masyarakat di Desa Salido sebagian besar masih menggunakan ember untuk beberapa keperluan seperti mandi, mencuci pakaian, mencuci piring, menampung air hujan, dll ditambah dengan kurangnya kepedulian membersihkan tempat penampungan air sehingga ditemukan ember yang positif larva nyamuk. Tempat penampungan air selanjutnya yang terbanyak ditemukan larva adalah bak mandi, ini disebabkan oleh masyarakat jarang untuk menguras bak mandi.

Hasil penelitian ini berbeda dengan penelitian Mardiah dan Rawina (2013) di RW 3 dan RW 7 Kelurahan Cempaka Putih Barat Jakarta Pusat, tidak ada perbedaan yang signifikan antara RW 3 dan RW 7, didapatkan kontainer di dalam rumah yang terbanyak positif larva adalah bak mandi. ${ }^{18}$ Perbedaan jenis kontainer yang terbanyak ini dikarenakan di Desa Salido masih banyak rumah yang menggunakan ember sebagai TPA dan belum memiliki bak mandi secara permanen sehingga menggunakan ember sebagai alternatif. Hal ini juga didukung pada saat survei ditemukan ditemukan total ember 266 buah dan tidak di semua rumah memiliki bak mandi.

Jenis kontainer diluar rumah di Desa Salido yang paling banyak ditemukan positif larva di luar rumah adalah ember bekas 34\% diikuti oleh ban bekas $22 \%$. Menurut Miller et al, kontainer di luar rumah merupakan jenis TPA yang tidak dapat dikontrol karena merupakan sampah dan biasanya terdapat di luar rumah serta tidak dapat digunakan dalam rumah tangga. Namun, bila terisi air hujan dapat menjadi tempat perkembangbiakan nyamuk jika tidak dibersihkan atau dikubur. ${ }^{5}$

Hasil penelitian ini berbeda dengan penelitian Purnama dan Baskoro (2012) didapatkan kontainer yang paling banyak larva di luar rumah adalah ban bekas $4.88 \%$ dengan kondisi tidak terurus dan sudah digunakan oleh rumah tangga. ${ }^{19}$ Perbedaan ini terjadi karena di Desa Salido masyarakat dominan menggunakan ember, sehingga bila ember sudah rusak atau tidak bisa dipakai lagi, maka ember tersebut di tumpuk di luar rumah sehingga dapat menjadi tempat perkembangbiakan larva. 
Penelitian lain yang mendukung menemukan bahwa ember bekas juga menjadi tempat yang potensial untuk perkembangan nyamuk adalah penelitian Tampi et al (2013) juga mendapatkan bahwa ember bekas memiliki nilai paling tinggi. Hasil penelitian ini berhubungan dengan kebiasaan masyarakat yang membiarkan ember tersebut di halaman serta kurang perhatiannya masyarakat pada lingkungannya, sehingga jika dibiarkan akan menyebabkan air hujan akan tertampung di dalamnya dan menjadi tempat perkembangbiakan nyamuk. $^{20}$

Hasil penelitian di Desa Salido paling banyak ditemukan keberadaan TPA yang positif larva berada di dalam rumah yaitu 81 kontainer sedangkan di luar rumah sebanyak 42 kontainer. Keberadaan kontainer di lingkungan rumah sangat berperan dalam perkembangbiakan nyamuk, karena semakin banyak kontainer sebagai tempat penampungan air dapat meningkatkan populasi nyamuk Ae. aegypti dan $A e$. albopictus sehingga menyebabkan tingginya risiko penularan penyakit DBD. Hasil yang sama didapat oleh Habibie et al (2017) dengan CS 39 kontainer positif larva dan 32 DS kontainer positif larva. ${ }^{17}$

Breteu Index (BI) merupakan jumlah penampungan air yang positif larva per-100 rumah yang diperiksa. BI merupakan index yang paling baik untuk memperkirakan kepadatan vektor karena $\mathrm{BI}$ mengkombinasikan rumah dengan kontainer. ${ }^{21}$ Apabila suatu wilayah memiliki nilai $\mathrm{BI}>30-50 \%$ dikatakan risiko tinggi terhadap penularan DBD dan nilai BI 5-20\% dikatakan berisiko rendah. ${ }^{14}$

Nilai BI di Desa Salido Pesisir Selatan adalah $123 \%$. Penelitian yang mendukung yaitu penelitian Novita et al (2017) yang mendapatkan nilai BI 102\% di Korong Gadang. ${ }^{21}$ Penentuan risiko penularan berdasarkan nilai $\mathrm{BI}$ menggunakan kategori DF menunjukkan bahwa penampungan air di dalam dan di luar rumah yang ditemukan pada rumah warga memiliki kategori $\mathrm{Bl}$ yang tinggi, sehingga mengakibatkan semakin tingginya kepadatan larva di daerah tersebut dan keadaan ini meningkatkan risiko terjadinya penularan penyakit DBD.

\section{Maya Indeks}

Penelitian yang dilakukan di Desa Salido didapatkan 93 rumah dengan maya indeks rendah dan 7 rumah dengan maya indeks sedang. Total rerata perhitungan $\mathrm{BRI}$ dan $\mathrm{HRI}$ pada Tabel 3, status maya indeks di Desa Salido Kecamatan IV Jurai Kabupaten Pesisir Selatan paling banyak termasuk risiko rendah menjadi tempat perkembangbiakan nyamuk $A e$. aegypti. Hasil studi ini sama dengan laporan penelitian Habibie et al (2017) di Kelurahan Ibuh Kota Payakumbuh. Kelurahan Ibuh memiliki potensi rendah penularan penyakit DBD, namun keadaan ini tetap perlu dikendalikan sehingga nilai Ml tidak semakin tinggi dan kasus DBD bisa diturunkan. ${ }^{17}$

Hasil ini berbeda dengan laporan Purnama dan Baskoro (2012) di Denpasar Selatan didapatkan kategori tinggi. Kondisi Maya Index yang tinggi meningkatkan terjadinya penularan infeksi DBD di suatu wilayah. $^{19}$

\section{Status Kerentanan}

Hasil penelitian terhadap status kerentanan larva nyamuk Ae. aegypti terhadap Temephos $0.012 \mathrm{di}$ Desa Salido Kecamatan IV Jurai sudah resistensi karena rerata kematian larva nyamuk adalah $8.33 \%$. Hasil ini sesuai dengan kriteria WHO, jika rerata kematian larva $<80 \%$ sudah resistensi. ${ }^{15}$ Resistensi ini dapat terjadi karena faktor penggunaan Temephos dalam jangka waktu lama dan penggunaan yang tidak sesuai aturan. Hasil wawancara dengan beberapa masyarakat di Desa Salido mengatakan bahwa Temephos dibagikan saat kejadian DBD, walaupun tidak semua kejadian DBD dilakukan pembagian Temephos. sehingga kami bisa membelinya di pedagang yang memasarkannya secara bebas. Masyarakat Desa Salido sebagian besar bekerja sebagai petani yang masih menggunakan insektisida sebagai pembunuh hama, hal ini juga bisa mempengaruhi resistensi terhadap Temephos. Hasil ini sesuai dengan Sungkar (2002) pemakaian insektisida terus menerus dan dalam jangka waktu lama dapat menimbulkan pencemaran lingkungan, membunuh fauna hingga terjadinya resistensi. ${ }^{11}$ 
Berbeda dengan Habibie et al (2017) di Kelurahan Ibuh Kota Payakumbuh yang mendapatkan status kerentanan terhadap Temephos dengan dosis $0.012 \mathrm{mg} / \mathrm{L}$ masih rentan. Hal ini terjadi karena masyarakat yang sadar akan kebersihan lingkungan yang sadar akan managemen pemberantasan sarang nyamuk. ${ }^{17}$

\section{Lethal time 50 dan Lethal time 99}

Penghitungan menggunakan uji probit, didapatkan kematian larva 50\% (LT50) dicapai pada menit ke 1826.77 dan kematian larva 99\% (LT99) dicapai pada menit ke 2475.42 dari hasil tersebut, pemakaian Temephos $0,012 \mathrm{mg} / \mathrm{L}$ akan efektif setelah penggunaan lebih dari 30 jam.

Hasil ini berbeda dengan penelitian Habibie et al (2017) di Kelurahan Ibuh dengan pemakaian Temephos 0.012 di dapatkan LT50 dicapai pada menit 710.40 dan LT99 pada menit 1456,74. Konsentrasi lainnya yang di gunakan Habibie et al (2017) yaitu Temephos 0.02 didapatkan LT 50 dicapai pada menit 70.77 dan LT 50 dicapai pada menit 100,75 . $^{17}$

\section{SIMPULAN}

Survei entomologi di Desa Salido Kecamatan IV Jurai Kabupaten Pesisir Selatan didapatkan HI 57\%, Cl 22.04\%, BI $123 \%$ dan kepadatan larva Ae. aegypti berada pada kepadatan Tinggi dengan DF 7 .

Maya index di Desa Salido Kecamatan IV Jurai Kabupaten Pesisir Selatan adalah 93 rumah dengan maya indeks rendah dan 7 rumah dengan maya indeks sedang.

Status kerentanan larva Ae. Aegypti di Desa Salido Kecamatan IV Jurai Kabupaten Pesisir Selatan sudah resisten terhadap Temephos $0.012 \mathrm{mg} / \mathrm{L}$.

\section{DAFTAR PUSTAKA}

1. World Health Organization (WHO). Dengue. guidlines for diagnosis,treatment, prevention and control new edition. Geneva: WHO; 2009.

2. Kementerian Kesehatan Republik Indonesia. Profil kesehatan Indonesia 2014. Jakarta:Kementrian Kesehatan RI. 2015. hIm.153-5.
3. Kementerian Kesehatan Republik Indonesia. Infodatin DBD. Situasi DBD di Indonesia. 2016 (diunduh Agustus 2017) Tersedia dari: http://www.depkes.go.id/resources/ download/pusdatin/infodatin/infodatin-dbd-2016.pdf

4. WHO. Panduan lengkap pencegahan \& pengendalian dengue \& DBD (Alihbahasa: Palupi Widyastuti). New Delhi: Regional Office for South East Asia Region; 2001. Jakarta: EGC; 2012.

5. Miller JE, Martínez-Balanzar A, Gazga-Salinas D. Where Aedes aegypti live in Guerrero; using the Maya index to measure breeding risk. Dalam: Halstead SB, Gómez-Dantés H, Editor (penyunting). Dengue: A worldwide problem, a common strategy. México DF: Ministry of Health, Mexico and Rockefeller Foundation; 1992. hlm. 311-317.

6. Direktorat Jenderal Pengendalian Penyakit dan Penyehatan Lingkungan Departemen Kesehatan Republik Indonesia. Modul pengendalian penyakit DBD di Indonesia. Jakarta: Direktorat Jenderal Pengendalian Penyakit dan Penyehatan Lingkungan; 2011.

7. Kementerian Kesehatan Republik Indonesia. Pemberantasan Sarang Nyamuk Demam Berdarah Dengue (PSN DBD) oleh Juru Pemantauan Jentik. Jakarta: Direktorat Jenderal Pengendalian Penyakit dan Penyehatan Lingkungan Departemen Kesehatan Republik Indonesia. 2007.

8. Kompes Departemen Pertanian. Metode Standar Pengujian Efikasi Pestisida. Jakarta: Departemen Pertanian. 2007

9. WHO Regional Office for South-East Asia. Comprehensive guidelines for prevention and control of dengue and dengue haemorrhagic fever. India: WHO; 2011.

10. American Cyanamid Company Agricultural Products Research Division. Abate larvicide. US: Trademark of America Cyanamid Company; 1998

11. Sungkar S. Pemberantasan demam berdarah dengue. sebuah tantangan yang harus dijawab. Jakarta: Majalah Kedokteran Indonesia. 2007;57 (6):167-70 
12. Service MW. Mosquito ecology field sampling methods. London: Chapman and Hall;1993.

13. WHO-SEARO. Pencegahan dan penanggulangan penyakit demam dengue dan demam berdarah dengue. Jakarta: Departemen Kesehatan RI; 2004.

14. WHO. A Review of entomological sampling method and indicators for dengue vector. WHO; 2003.

15.WHO. Monitoring and managing insecticide resistance in Aedes mosquito populations. 2016 (diunduh Agustus 2017). Tersedia dari: http://apps.who.int/iris/bitstream/handle/10665/204 588/WHO ZIKV VC 16.1 eng.pdf;jsessionid=2B5 4329F4538C6F2CA3430BD86EF9EB8?sequence

16. Direktorat Jenderal Pengendalian Penyakit dan Penyehatan Lingkungan Departemen Kesehatan Republik Indonesia. Modul pengendalian penyakit DBD di Indonesia. Jakarta: Direktorat Jenderal Pengendalian Penyakit dan Penyehatan Lingkungan; 2011.

17. Habibie AM, Hasmiwati, Wahyudi. Kepadatan populasi, status maya index dan uji kerentanan larva Aedes aegypti di Kelurahan Ibuh Kota Payakumbuh tahun 2017 (skripsi). Padang: Fakultas Kedokteran Universitas Andalas; 2017.

18. Mardiah S, Rawina W. Perbandingan keberadaan larva Aedes sp pada kontainer dalam rumah antara RW 03 dan RW 07 Kelurahan Cempaka Putih Barat, Jakarta Pusat (skripsi). Jakarta: Fakultas Kedokteran Universitas Indonesia; 2013.

19. Purnama SG, Baskoro T. Maya index dan kepadatan larva Aedes aegpyti terhadap infeksi dengue. Makara Kesehatan. 2012;16(2):57-64.

20. Tampi FH, Runtuwene J, Pijoh VD. Survei jentik nyamuk Aedes spp di Desa Teep Kecamatan Amurang Barat Kabupaten Minahasa Selatan. Jurnal e- Biomedik. 2013;1(1): 260-4.

21. Novita E, Hasmiwati, Rusdji SR, Irawati N. Analysis of indicators entomology Aedes aegypti in endemic areas of dengue fever in Padang, West Sumatera, Indonesia. International Journal of mosquito Research. 2017;4(2):57-9. 